\title{
The increased incidence of bony metastasis in p16-positive oropharyngeal carcinoma, a method to enhance reliability and speed for performing anterior rhinomanometry, and the new Soundbridge middle-ear implant and magnetic resonance imaging compatibility
}

The paper by Harris et al. ${ }^{1}$ in this month's issue of The Journal of Laryngology \& Otology examines the incidence of bony metastases in oropharyngeal cancer and the difference human papilloma virus (HPV) positivity makes to this. The emergence of HPV is well known, and the need for risk stratification ${ }^{2}$ and survival outcomes $^{3}$ are of interest. Bony metastases are rare in oropharyngeal squamous cell carcinoma. Harris and colleagues ${ }^{1}$ looked at 180 consecutive patients over 5 years, and found that the expression of p16 was associated with a significant incidence of bony metastasis in this cohort. This study seeks to answer a specific question and is an important addition to the literature.

The study by Arslan et $a l .{ }^{4}$ describes a simple and elegant method of improving the reliability and speed of performing anterior rhinomanometry. The authors describe preparing the nasal skin using benzoin tincture solution before placing foam tapes. This achieves better adhesion, shortens the procedure duration and significantly increases the test reliability.

Todt and colleagues ${ }^{5}$ examined the effects of magnetic resonance imaging (MRI), at $1.5 \mathrm{~T}$, in a small group of patients who were implanted with the new Vibrant Soundbridge $^{\mathrm{TM}}$ implant VSB 503, and found this to be free of the complications that they had previously encountered with the Vibrant Soundbridge 502 generation implants. ${ }^{6}$ These complications included pain and transfer function from the floating mass transducer dislocations. Although a limited study, the new Vibrant Soundbridge type 503 generation device seems to offer better compatibility with MRI scanning. The number of patients who have received a Vibrant Soundbridge implant in the UK is small, but this is on the increase. As more and more situations arise where MRI becomes necessary in these implanted patients, information on MRI compatibility becomes more relevant and important.
On a different note, we would like to acknowledge our senior editor Robin Youngs, who has been an Editor of The Journal from 2005, and who retires from the editorship this month. Robin leaves The Journal in excellent shape; he has worked very hard to serve our readers, and to contribute to knowledge and the specialty. He was successful in all he undertook; the number of initiatives and innovations that he has been responsible for has enriched The Journal and the mission of the charity. This will remain his hallmark. We are delighted that he has accepted to be Editor Emeritus.

\section{MUSHEER HUSSAIN EDWARD FISHER JONATHAN FISHMAN Senior Editors}

\section{References}

1 Harris AS, Thomas RG, Passant CD. Do patients with p16positive oropharyngeal squamous cell carcinoma get more bone metastasis than p16-negative patients? J Laryngol Otol 2018; 132:429-33

2 Hamilton D, Khan MK, O'Hara J, Paleri V. The changing landscape of oropharyngeal cancer management. J Laryngol Otol 2017;131:3-7

3 Kao SS, Ooi EH. Survival outcomes following salvage surgery for oropharyngeal squamous cell carcinoma: systematic review. $J$ Laryngol Otol 2018;132:299-313

4 Arslan F, Yıldızoğlu U, Durmaz A, Çetinkaya S. Improving the rhinomanometry technique using benzoin tincture. J Laryngol Otol 2018;132:404-7

5 Todt I, Mittmann P, Ernst A, Mutze S, Rademacher G. In vivo experiences with magnetic resonance imaging scans in Vibrant Soundbridge type 503 implantees. J Laryngol Otol 2018;132: 401-3

6 Todt I, Wagner J, Goetze R, Scholz S, Seidl R, Ernst A. MRI scanning in patients implanted with a Vibrant Soundbridge. Laryngoscope 2011;121:1532-5 